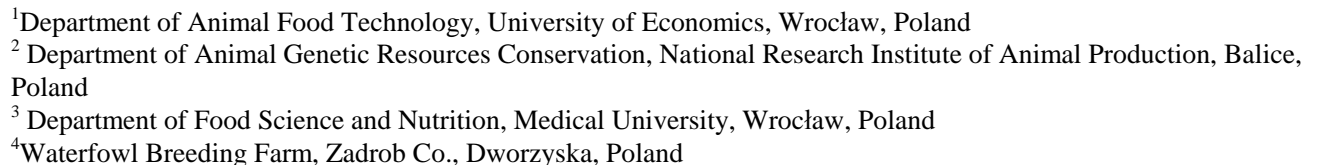

\title{
Comparison of amino acid and fatty acid composition of duck breast muscles from five flocks
}

\begin{abstract}
A total of 60 drakes out of three flocks of conservative Miniduck (K2), Polish Pekin (P33), native Pekin population type A3 and two breeding strains (A55, P66), aged seven weeks, were used for comparison. The content of protein, lipids, moisture, essential amino acids, fatty acids and cholesterol were estimated. There were differences among flocks in all biochemical parameters. The muscles of A55 and P66 comprised more protein and less moisture than P33 and A3 muscles. The P33 breast muscles comprised the least of lipids $(0.8 \% \mathrm{v} / \mathrm{s}$ 1.16-1.32\%), however A55 of cholesterol (71.21mg/100g v/s 82.23-111.82 mg/100g). The isoleucine (ILE) and valine (VAL) were amino acids which limited the biological value of meat proteins from breast muscles of $\mathrm{A} 3$, P33 and K2, however tryptophan (TRP) for A55, P66 muscles. The unsaturated fatty acids (UFA) were predominant for all flocks (50.12-60.64\%), the P66 muscles contained the most of UFA and P33 the most of saturated fatty acids (SFA). The highest level of polyunsaturated fatty acids (PUFA) was established in K2 muscles. The PUFA/SFA and n-6/n-3 PUFA ratios were 0.63-0.84 and 3.22-5.85 respectively. The lipids of A55 were characterized by the best fatty acid profile among the investigated muscles. Taking into consideration the nutritive value of proteins, cholesterol content and profile of fatty acids, A55 breast muscles appeared to be the most favourable from the human health point of view.
\end{abstract}

Key Words: ducks, breast muscles, amino acid composition, fatty acid composition

\section{Zusammenfassung}

Titel der Arbeit: Vergleich der Aminosäure- und Fettsäurezusammensetzung der Brustmuskeln bei fünf Entenpopulationen

Es wurden Brustmuskeln bei fünf Linien von Pekingenten P33, A3 und Minienten K2 aus der Genreserve sowie A55 und P66 als Fleischselektionslinien, verglichen. Jeweils sechs Erpel wurden in einem Alter von sieben Wochen geschlachtet und der Gehalt an Protein, Lipid, Wasser, Aminosäuren, Cholesterin und Fettsäuren bestimmt. Die Populationen unterschieden sich in einer Reihe von Merkmalen. So enthielten die Brustmuskeln der Selektionslinien A55 und P66 signifikant mehr Protein und weniger Wasser als die der Genreserve P33 und A3. Den geringsten Gehalt an Lipiden wiesen die Genreserve P33 und an Cholesterin die Selektionslinie A55 auf. Relativ niedrig war der Gehalt an essentiellen Aminosäuren wie ILE und VAL bei sämtlichen Genreserven, der TRP Gehalt dagegen bei beiden Selektionslinien.

Der relativ höchste Anteil an ungesättigten Fettsäuren (UFA) fand sich bei den Selektionslinien, während die Linie K2 den höchsten Anteil polyungesättigter Fettsäuren (PUFA) enthielt. Das Verhältnis von n-6/n-3 variierte zwischen 3,27 bis 5,68 und UFA/SFA zwischen 0,63 bis 0,84. Das beste Fettsäuremuster aller verglichenen Brustmuskelproben erreichte die Selektionslinie A55. Alle Populationen zeichneten sich durch einen hohen Nährwert für die menschliche Ernährung aus, wobei sich die Linie A55 besonders hervorhob.

Schlüsselwörter: Enten, Brustmuskeln, Aminosäuremuster, Fettsäuremuster

\section{Introduction}

In Poland, at present eight conservative and genetic reserve flocks of ducks are under the conservation program. Two conservative flocks of Polish origin ducks i.e. Pekin 
(P33) and Miniduck (K2) have been listed by FAO (WORLD WATCH LIST, 2000) and registered as the protected world genetic resources. These conservative flocks were used in the development of new breeding and experimental strains and synthetic lines as well as in the search for heterosis effects in commercial sets. The maintenance program for the preservation of duck genetic resources, is carried out in National Research Institute of Animal Production in Balice near Kraków. There have been selected five strains (A44, A55, P66, P77, K11) of meat type ducks which were recognized by Polish Ministry of Agriculture and Country Development as breeding strains. The populations of P33, K2, A3 belonging to the conservative flocks and A55, P66 ducks have been tested for reproductive and meatiness traits so far (KSIAZŻKIEWICZ, 1997, 2002).

The previous studies of meat quality and carcass traits, confirmed differentiation between species and strains such as: body weight, percentage yield of muscles, skin with subcutaneous fat and abdominal fat in the carcass. Besides, it is well known, that meat of several genotypes and strains of ducks differ in the nutritional value (proportion of protein, fat, moisture, cholesterol, amino acid and fatty acid composition) (PINGEL, 1988; SMITH et al., 1993, IŞGUZAR et al., 2002 KSIĄŻKIEWICZ, 2002, 2003; KISIEL and KSIĄŻKIEWICZ, 2004; WAWRO et al., 2004).

Generally, the meat is recognized as one of the main sources of protein for human nutrition. From the nutritional point of view, it is very important to know not only the protein content but the amino acid composition as well.

The excess of fat, and of some SFA and cholesterol in the diet have been harmful to human health. On the other hand the UFA and especially the PUFA have been essential for our organism. Dietary fat may effect human health in a number of ways, by affecting risk of cancer, obesity, diabetes and of coronary heart disease (PFEUFFER, 2001). Because the general opinion is that, the cholesterol and inappropriate ratio of polyunsaturated and saturated fatty acids are main causes of cardiovascular diseases, the determination of cholesterol content and fatty acids in meat is very important too.

There are no adequate data on the chemical composition comprising amino acid composition of protein and fatty acid profile of lipids from muscles of the above mentioned flocks. This was the reason for undertaking the investigation on this subject.

\section{Materials and methods}

For the experiment were used ducks of three conservative flocks and two selected breeding strains maintained by in situ method in the Department of Poultry Breeding in Dworzyska near Poznań.

The characteristic of these ducks was given in Table1.

During the testing period ducks were reared up to the fourth week of age in a poultry house of controlled air temperature, and afterwards they were kept on yards of restricted area, partially shedded and covered with straw.

All birds were fed ad libitum on the same complete feeds (Table 2). This diet was given until the third week of age contained $20 \%$ of crude protein and $12.13 \mathrm{MJ}$ metabolizable energy and later $16.5 \%$ of crude protein and $12.34 \mathrm{MJ}$ metabolizable energy per $1 \mathrm{~kg}$ of feed. 
Table 1

Material used for investigation (Untersuchungsmaterial)

\begin{tabular}{|c|c|c|}
\hline Flock & Origin of duck's & Characteristic \\
\hline P33 & $\begin{array}{l}\text { Polish Pekin-the native and } \\
\text { old indigenous breeding strain } \\
\text { (conservative).* }\end{array}$ & $\begin{array}{l}\text { It has white plumage with no special pattern of feathers, } \\
\text { yellow skin, shanks and feet and white eggshells (137 } \\
\text { eggs/laying period). Adult males weigh } 3400 \text { and } \\
\text { females } 3150 \mathrm{~g} \text { on average. The birds are known for } \\
\text { good quality feathers, good productivity, satisfactory } \\
\text { reproductive performance and low skin and } \\
\text { subcutaneous fat content in carcass. }\end{array}$ \\
\hline K2 & $\begin{array}{l}\text { Miniduck- bred from wild mallards } \\
\text { (Anas platyrhynchos L.) and Pekin type } \\
\text { ducks (conservative).* }\end{array}$ & $\begin{array}{l}\text { It has white plumage with no special feather pattern, } \\
\text { white skin, yellow shanks and feet, eggshells that may } \\
\text { greenish ( } 50 \%) \text { or white (50\%) in colour. It is a } \\
\text { medium-sized duck with an adult male weighing } 1700 \\
\text { and a female } 1600 \mathrm{~g} \text { on average. The birds are } \\
\text { characterized by very well developed muscles and low } \\
\text { fatness. The birds are characterized by a low number of } \\
\text { laid eggs ( } 90 \text { eggs/ laying period) but good hatching } \\
\text { parameters. }\end{array}$ \\
\hline A3 & $\begin{array}{l}\text { Pekin population, A3, originated from } \\
\text { England, included to conservative and } \\
\text { genetic reserve locks of ducks by Polish } \\
\text { Ministry of Agriculture and Country } \\
\text { Development in } 1986 \text { ( conservative).* }\end{array}$ & $\begin{array}{l}\text { It has self-white plumage, yellow skin, shanks and feet, } \\
\text { yellow or pink beaks, white or greenish eggshells ( } 147 / \\
\text { eggs/laying period). Adult males weigh } 3100 \text { and } \\
\text { females } 3000 \text { g. They are characterized by good } \\
\text { meatiness and adequate reproductive performance. }\end{array}$ \\
\hline A55 & $\begin{array}{l}\text { Sire strain, meat type, was obtained by } \\
\text { crossing A44 (was bred from Pekin and } \\
\text { Aylesbury and selected over } 22 \text { years ) } \\
\text { with P8 ( Pekins of Danish origin) and } \\
17 \text { consecutive years of selection.** }\end{array}$ & $\begin{array}{l}\text { It has self-white colour plumage, yellow shanks and } \\
\text { feet, yellow or orange beak. The birds grow rapidly, } \\
\text { and adult birds reach about } 3000 \text { g body weight. They } \\
\text { characterized by good meatiness, low fatness and very } \\
\text { good reproductive performance. }\end{array}$ \\
\hline P66 & $\begin{array}{l}\text { Maternal strain, selected meat type, bred } \\
\text { from Pekins originating from Poland.** }\end{array}$ & $\begin{array}{l}\text { It has the white colour plumage, dark yellow shanks and } \\
\text { feet and long orange beak. The adult birds reach about } \\
2600 \mathrm{~g} \text { body weight. The A55 male and P66 female } \\
\text { ducks have been the parental combination for broiler } \\
\text { production. The parental combinations of those strains } \\
\text { for production of two strain crosses have been } \\
\text { characterized by high lying, fertilization, and hatching as } \\
\text { well as good vitality. The two strain crosses have been } \\
\text { characterized by very good musculature, low fatness and } \\
\text { big feed efficiency per } 1 \mathrm{~kg} \text { gain. }\end{array}$ \\
\hline
\end{tabular}

*KSIĄŻKIEWICZ, 2002; **MAZANOWSKI, 2002

Table 2

Diet composition used in the trial (Futterzusammensetzung während der Versuche)

\begin{tabular}{lll}
\hline Ingredients & $1-21$ days & $22-49$ days \\
\hline Wheat meal (\%) & 72.8 & 57.6 \\
Soybean meal (\%) & 17.0 & 10 \\
Barley meal (\%) & 17.4 & - \\
Rapeseed oil (\%) & 1.0 & 1.6 \\
Calcium carbonat (\%) & 0.8 & 6.0 \\
Dicalcium phosphate (\%) & 2.0 & 2.0 \\
Premix KB ( vitamin- mineral & 1.0 & 1.4 \\
premix) (\%) & & \\
Fish meal (\%) & 5.4 & 4.0 \\
\hline
\end{tabular}


In the seventh week of age, from each flock six males having body weight close to the arithmetic mean of body weight in particular flock were taken for analysis (Table 3).

Table 3

Experimental design (Versuchsaufbau)

\begin{tabular}{lrrrrr}
\hline & \multicolumn{5}{c}{ Flock } \\
Specification & P33 & K2 & A3 & A55 & P66 \\
\hline Number of male birds: & 60 & 60 & 60 & 60 & 60 \\
reared & 6 & 6 & 6 & 6 & 6 \\
slaughtered & 7 & 7 & 7 & 7 & 7 \\
Age at slaughter( weeks) & 2342 & 1582 & 2475 & 2869 & 2617 \\
Weight at slaughter (g) & &
\end{tabular}

The killing of birds and cutting of breast muscles were made manually. The breast muscles were held at $2-4^{0} \mathrm{C}$ until $24 \mathrm{~h}$ after killing and next examined. Each kind of muscle was separately minced in a meat grinder (diameter $2 \mathrm{~mm}$ ) and mixed in the food processor Büchi Mixer B-400 to obtain a homogeneous mass.

Chemical analyses in homogenates were carried out using the following methods:

- Moisture, protein, and lipids - were determined with standard methods (A.O.A.C., 1990).

- Cholesterol - using the enzymatic Human test in an extract prepared by FOLCH et al. (1957) procedure. The saponification was carried out by RHEE et al. (1982) method. The preparation of samples and the method's of analysis were given in the paper of SKRABKA- BŁOTNICKA et al. (1997).

- Amino acid composition -was determined using HPLC Chromatograph MIKROTECHMA Amino Quant AAA T 339 type ( Czech Republic) according to manufacturer's recommendations. The acid hydrolysis of meat samples was made with $6 \mathrm{M} \mathrm{HCl}$ in the environment without oxygen in a nitrogen atmosphere at $105^{\circ} \mathrm{C}$ for $24 \mathrm{~h}$. Tryptophan was determined from the alkaline hydrolyzate ( saturated solution of $(\mathrm{BaOH})_{2}$ at $110^{\circ} \mathrm{C}$ for $48 \mathrm{~h}$ ) by the method described by SKARBKA- BŁOTNICKA ( 1973).

- The limited amino acid index (R\%) for breast (BM) muscles were established according to he formula: $\mathbf{R}(\%)=100 \% \times \mathrm{A}_{\mathrm{m}} / \mathrm{A}_{\mathrm{s}},\left(\mathrm{A}_{\mathrm{m}}\right.$ - essential amino acid content in the duck meat protein; $A_{s}$ - essential amino acid content in the standard FAO).

- The composition of fatty acids was determined using gas chromatography technique with the AGILENT Tech. 6890N Chromatograph, equipped with a flame ionization detector. The fat from muscles was extracted with the chloroform by FOLCH et al. (1957) procedure. The methyl esters of fatty acids were obtained by means of esterification of lipid samples according to the PRESCHA et. al. ( 2001). The methyl esters of fatty acids were separated on the fused silica CP-Sil 88 (Chrompack, Netherlands) capillary column (100 x $0.25 \mathrm{~mm}$ ), helium was used as the carrier gas. The separation was conducted at the programmed temperature from 165 to $200^{\circ} \mathrm{C}$ by increase rate at $2^{0} \mathrm{C} / \mathrm{min}$. The identification of fatty acids was accomplished by comparison with external standards. The fatty acids were calculated as \% of total fatty acids with the ChemStation v.4.0 Agilent Technologies programme. 
- Statistical analysis was based on arithmetic means (X) and standard deviation (sd). The effects of flock were analysed by one way analysis of variance (ANOVA) in a non-orthogonal scheme. Significant differences between the average values were determined by Duncan's multiple range test. The statistical analysis was conducted with the Software System Statistica, version 6.0 (STATSOFT INC., 2001).

\section{Results}

Comparing the chemical composition of breast muscles, the significant differences in all parameters were found, in spite of the fact all the birds were fed on the same diet. The A55 and P66 breast muscles of breeding strains comprised more protein and less moisture than that of P33 and A3 conservative flocks. The P33 muscles demonstrated the lowest amounts of lipids, however A55 of cholesterol (Table 4).

Table 4

Basic chemical composition of breast muscles (Chemische Grundzusammensetzung der Brustmuskeln)

\begin{tabular}{|c|c|c|c|c|c|}
\hline \multicolumn{2}{|l|}{ Flock } & Protein (\%) & Lipids (\%) & Moisture (\%) & Cholesterol (mg/100g) \\
\hline \multirow{2}{*}{ P33 } & $\bar{x}$ & $20.25^{\mathrm{a}}$ & $0.80^{\mathrm{a}}$ & $77.70^{\mathrm{a}}$ & $95.17^{\mathrm{a}}$ \\
\hline & sd & 0.277 & 0.097 & 0.523 & 7.98 \\
\hline \multirow{2}{*}{ K2 } & $\bar{x}$ & $20.91^{\mathrm{a}}$ & $1.16^{\mathrm{b}}$ & $76.67^{\mathrm{b}}$ & $111.82^{\mathrm{b}}$ \\
\hline & sd & 0.246 & 0.111 & 0.535 & 9.67 \\
\hline \multirow{2}{*}{ A3 } & $\bar{x}$ & $19.53^{\mathrm{a}}$ & $1.28^{\mathrm{b}}$ & $77.53^{\mathrm{a}}$ & $106.05^{\mathrm{b}}$ \\
\hline & sd & 0.189 & 0.101 & 0.543 & 010.91 \\
\hline \multirow{2}{*}{ A55 } & $\bar{x}$ & $21.37^{\mathrm{b}}$ & $1.32^{\mathrm{b}}$ & $75.86^{\mathrm{b}}$ & $71.21^{\mathrm{c}}$ \\
\hline & sd & 0.277 & 0.093 & 0.533 & 7.06 \\
\hline \multirow{2}{*}{ P66 } & $\bar{x}$ & $21.81^{\mathrm{b}}$ & $1.32^{\mathrm{b}}$ & $76.10^{\mathrm{b}}$ & $82.23^{\mathrm{d}}$ \\
\hline & sd & 0.516 & 0.098 & 0.537 & 7.57 \\
\hline \multicolumn{2}{|c|}{ Effect of flock } & $*$ & $*$ & $*$ & $* *$ \\
\hline
\end{tabular}

$\overline{\mathrm{x}}$ - average values from 6 tests, sd- standard deviation,

a,b,c,d - values with different superscriptions at the same column are significantly different. :. .s. $=$ not significant, $*=p<0.05$, ${ }^{* *}=p<0.01$

Table 5

Essential amino acids composition of breast muscles protein (\% of total protein) (Aminosäurenmuster der Brustmuskelproteine (in \% des Gesamtproteins))

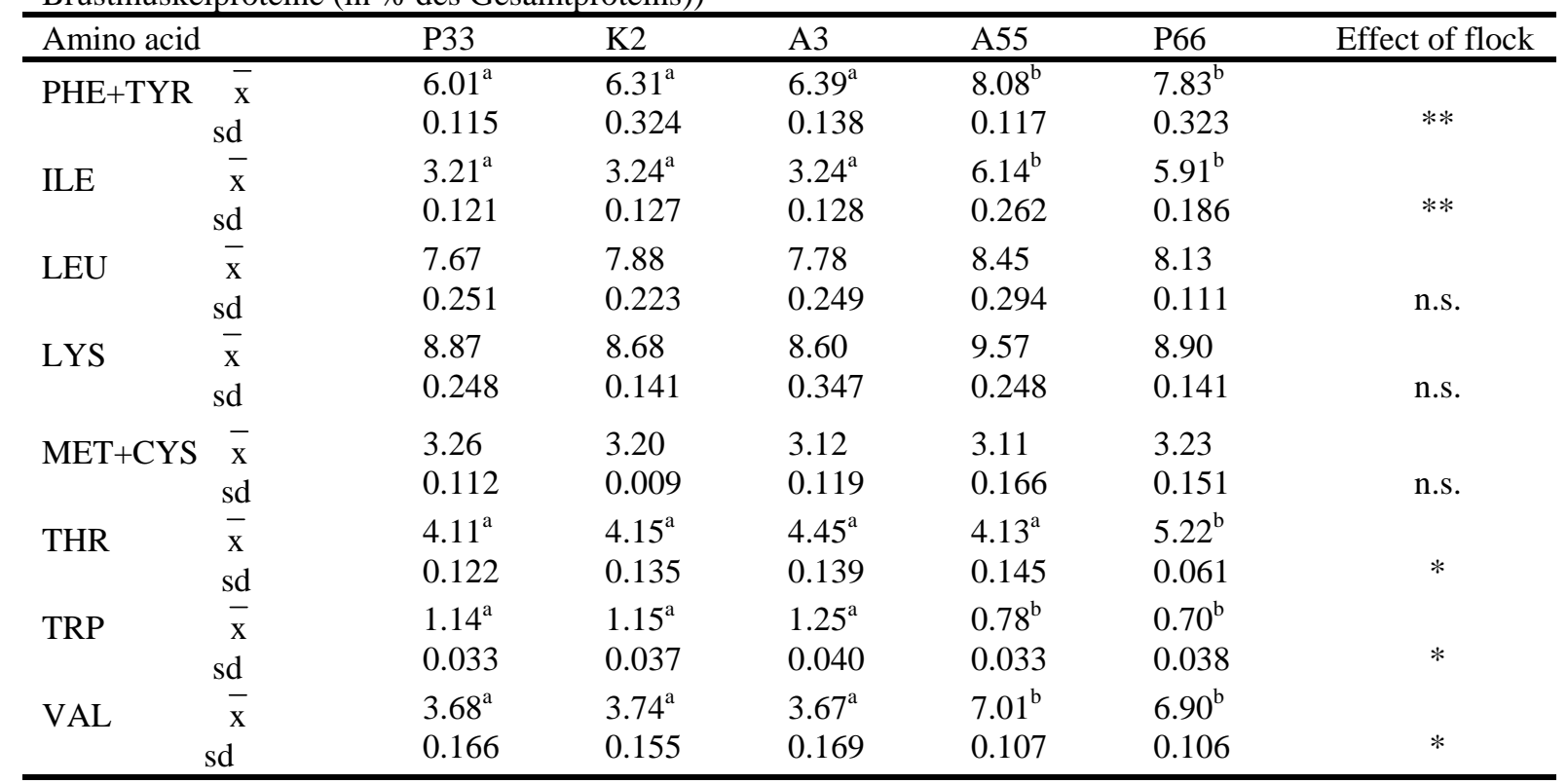

$\overline{\mathrm{x}}$ - average values from 6 tests, sd- standard deviation,

a,b,- values with different superscriptions at the same level are significantly different. :n.s. $=$ not significant, $*=p<0.05$, $* *=p<0.01$ 
The muscles of investigated ducks contained all essential amino acids. The amino acid proportion of meat proteins depended on ducks' flocks and differ from the genotype significantly. The breast muscles from A55 and P66 selected strains comprised more PHE+TYR, ILE and VAL and less TRP as compared to muscles of A3, P33 and K2 conservative flocks (Table 5).

Table 6

Limited amino acids index (R\%) (Index der limitierenden Aminosäuren (R\%))

\begin{tabular}{llllll}
\hline Amino acid & P3 & K2 & A3 & A55 & P66 \\
\hline PHE + TYR & 99.0 & 105.0 & 106.5 & 134.6 & 130.5 \\
ILE & 81.7 & 81.0 & 81.0 & 157.2 & 151.5 \\
LEU & 108.3 & 112.6 & 111.1 & 122.5 & 117.8 \\
LYS & 159.2 & 157.8 & 156.4 & 174.0 & 161.8 \\
MET + CYS & 92.0 & 90.0 & 89.1 & 89.0 & 92.2 \\
THR & 101.5 & 103.8 & 111.2 & 103.2 & 130.5 \\
TRP & 113.0 & 115.0 & 125.0 & 78.0 & 70.0 \\
VAL & 72.6 & 74.8 & 73.4 & 140.2 & 138.6 \\
\hline
\end{tabular}

Table 7

Fatty acids composition of lipids from breast muscles (Fettsäuremuster der Lipide der Brustmuskeln)

\begin{tabular}{|c|c|c|c|c|c|c|c|}
\hline $\begin{array}{l}\text { Fatty } \\
(\%)\end{array}$ & acid & P33 & K2 & A3 & A55 & P66 & Effect of flock \\
\hline $\mathrm{C}_{14}$ & $\begin{array}{r}\overline{\mathrm{X}} \\
\mathrm{sd}\end{array}$ & $\begin{array}{c}0.82^{\mathrm{a}} \\
0.09\end{array}$ & $\begin{array}{c}0.65^{\mathrm{b}} \\
0.09\end{array}$ & $\begin{array}{c}0.74^{\mathrm{a}} \\
0.08\end{array}$ & $\begin{array}{c}0.65^{\mathrm{b}} \\
0.09\end{array}$ & $\begin{array}{c}0.64^{\mathrm{b}} \\
0.09\end{array}$ & $*$ \\
\hline $\mathrm{C}_{16}$ & $\begin{array}{l}\bar{x} \\
\text { sd }\end{array}$ & $\begin{array}{c}24.31^{\mathrm{a}} \\
0.48\end{array}$ & $\begin{array}{c}22.58^{\mathrm{b}} \\
0.51\end{array}$ & $\begin{array}{c}22.32^{\mathrm{b}} \\
0.47\end{array}$ & $\begin{array}{c}21.86^{\mathrm{b}} \\
0.65\end{array}$ & $\begin{array}{c}22.30^{\mathrm{b}} \\
0.57\end{array}$ & $*$ \\
\hline $\mathrm{C}_{16: 1}$ & $\begin{array}{c}\bar{x} \\
\text { sd }\end{array}$ & $\begin{array}{c}1.12^{\mathrm{a}} \\
0.09\end{array}$ & $\begin{array}{l}1.21^{\mathrm{a}} \\
0.11\end{array}$ & $\begin{array}{l}1.55^{\mathrm{a}} \\
0.14\end{array}$ & $\begin{array}{c}2.45^{\mathrm{b}} \\
0.17\end{array}$ & $\begin{array}{c}2.08^{b} \\
0.18\end{array}$ & $*$ \\
\hline $\mathrm{C}_{18}$ & $\begin{array}{r}\bar{x} \\
\text { sd }\end{array}$ & $\begin{array}{c}12.74^{\mathrm{a}} \\
0.41\end{array}$ & $\begin{array}{c}13.78^{\mathrm{a}} \\
0.71\end{array}$ & $\begin{array}{c}10.69^{b} \\
0.35\end{array}$ & $\begin{array}{c}10.49^{b} \\
0.37\end{array}$ & $\begin{array}{c}10.33^{\mathrm{b}} \\
0.10\end{array}$ & * \\
\hline $\mathrm{C}_{18: 1}$ & $\begin{array}{l}\bar{x} \\
\text { sd }\end{array}$ & $\begin{array}{c}22.07^{\mathrm{a}} \\
0.52\end{array}$ & $\begin{array}{c}22.31^{\mathrm{a}} \\
1.27\end{array}$ & $\begin{array}{c}25.07^{\mathrm{b}} \\
1.08\end{array}$ & $\begin{array}{c}27.41^{\mathrm{C}} \\
0.79\end{array}$ & $\begin{array}{c}29.41^{\mathrm{d}} \\
0.99\end{array}$ & $* *$ \\
\hline $\begin{array}{l}\mathrm{C}_{18: 1} \\
\Sigma \text { ison }\end{array}$ & $\begin{array}{c}\bar{x} \\
\text { m.sd }\end{array}$ & $\begin{array}{l}2.76 \\
0.42\end{array}$ & $\begin{array}{l}3.02 \\
0.30\end{array}$ & $\begin{array}{l}3.71 \\
0.31\end{array}$ & $\begin{array}{l}3.76 \\
0.31\end{array}$ & $\begin{array}{l}2.77 \\
0.42\end{array}$ & n.s. \\
\hline $\mathrm{C}_{18: 2}$ & $\begin{array}{l}\bar{x} \\
\text { sd }\end{array}$ & $\begin{array}{c}14.28^{\mathrm{a}} \\
0.81\end{array}$ & $\begin{array}{c}14.69^{\mathrm{a}} \\
0.94\end{array}$ & $\begin{array}{c}12.52^{\mathrm{b}} \\
1.43\end{array}$ & $\begin{array}{c}14.20^{\mathrm{a}} \\
0.151\end{array}$ & $\begin{array}{c}14.13^{\mathrm{a}} \\
0.162\end{array}$ & $*$ \\
\hline $\mathrm{C}_{18: 3}$ & $\begin{array}{l}\bar{x} \\
\text { sd }\end{array}$ & $\begin{array}{l}1.62^{\mathrm{a}} \\
0.21\end{array}$ & $\begin{array}{c}0.83^{\mathrm{bc}} \\
0.08\end{array}$ & $\begin{array}{c}1.00^{\mathrm{b}} \\
0.07\end{array}$ & $\begin{array}{c}1.10^{\text {bd }} \\
0.06\end{array}$ & $\begin{array}{c}1.03^{\mathrm{b}} \\
0.09\end{array}$ & $*$ \\
\hline $\mathrm{C}_{20: 1}$ & $\begin{array}{l}\bar{x} \\
\text { sd }\end{array}$ & $\begin{array}{l}0.41 \\
0.03\end{array}$ & $\begin{array}{l}0.31 \\
0.04\end{array}$ & $\begin{array}{l}0.41 \\
0.02\end{array}$ & $\begin{array}{c}0.31 \\
0.021\end{array}$ & $\begin{array}{c}0.31 \\
0.025\end{array}$ & n.s. \\
\hline $\mathrm{C}_{20: 4}$ & $\begin{array}{l}\bar{x} \\
\text { sd }\end{array}$ & $\begin{array}{l}7.03^{\mathrm{a}} \\
0.42\end{array}$ & $\begin{array}{c}10.17^{\mathrm{b}} \\
0.51\end{array}$ & $\begin{array}{c}8.56^{c} \\
0.61\end{array}$ & $\begin{array}{c}7.11^{\mathrm{a}} \\
0.59\end{array}$ & $\begin{array}{c}7.49^{\mathrm{a}} \\
0.57\end{array}$ & $*$ \\
\hline $\mathrm{C}_{20: 5}$ & $\begin{array}{l}\bar{x} \\
\text { sd }\end{array}$ & $\begin{array}{c}0.59^{\mathrm{a}} \\
0.12\end{array}$ & $\begin{array}{c}0.44^{\mathrm{a}} \\
0.11\end{array}$ & $\begin{array}{c}0.49^{\mathrm{a}} \\
0.10\end{array}$ & $\begin{array}{l}1.12^{\mathrm{b}} \\
0,10\end{array}$ & $\begin{array}{c}0.91^{b} \\
0.13\end{array}$ & $*$ \\
\hline $\mathrm{C}_{21}$ & $\begin{array}{l}\bar{x} \\
\text { sd }\end{array}$ & $\begin{array}{c}0.60^{\mathrm{a}} \\
0.12\end{array}$ & $\begin{array}{c}0.38^{\mathrm{b}} \\
0.20\end{array}$ & $\begin{array}{c}0.85^{\mathrm{a}} \\
0.15\end{array}$ & $\begin{array}{c}0.71^{\mathrm{a}} \\
0,17\end{array}$ & $\begin{array}{c}0.61^{\mathrm{a}} \\
0.18\end{array}$ & $* *$ \\
\hline $\mathrm{C}_{22: 4}$ & $\begin{array}{l}\bar{x} \\
\text { sd }\end{array}$ & $\begin{array}{l}0.80 \\
0.09\end{array}$ & $\begin{array}{l}1.01 \\
0.09\end{array}$ & $\begin{array}{l}0.82 \\
0.05\end{array}$ & $\begin{array}{l}0.74 \\
0.07\end{array}$ & $\begin{array}{l}0.80 \\
0.08\end{array}$ & n.s. \\
\hline $\mathrm{C} 2_{2: 6}$ & $\begin{array}{c}\bar{x} \\
\text { sd }\end{array}$ & $\begin{array}{c}1.97^{\mathrm{a}} \\
0.21\end{array}$ & $\begin{array}{c}2.98^{b} \\
0.41\end{array}$ & $\begin{array}{c}3.38^{b} \\
0.41\end{array}$ & $\begin{array}{c}3.42^{b} \\
0.35\end{array}$ & $\begin{array}{c}3.40^{\mathrm{b}} \\
0.24\end{array}$ & $* *$ \\
\hline
\end{tabular}

$\overline{\mathrm{x}}$ - average values from 6 tests, sd- standard deviation,

a,b,c,d - values with different superscriptors at the same level are significantly different. :n.s. $=$ not significant, $*=p<0.05, * *=p<0.01$ 
The ILE and VAL were amino acids which limited the biological value of meat proteins from breast muscles of A3, P33 and K2, however TRP for A55, P66 muscles. They were characterized by the lower value of index $\mathbf{R}$ than the FAO standard (84\%) (Table 6).

Except of ILE and VAL for A33, P33, K2 and TRP for A55, P66 muscles, the meat proteins contained more essential amino acids than the FAO standard. The LYS was characterized by the highest value of index $\mathbf{R}$ (156.4-174.0\%) and thereby possessed the highest biological value among essential amino acids. Taking into consideration the biological value of proteins, A55 breast muscles appeared to be the most favourable.

In spite of the same environmental conditions (feed, housing conditions, age), the concentration of some fatty acids in the breast muscles was different. The kind of flocks affected on profile of fatty acids (Table 7).

In the investigated muscles the presence of the essential polyunsaturated fatty acids (PUFA) was observed such as: $\mathrm{C}_{18: 2}, \mathrm{C}_{18: 3}, \mathrm{C}_{20: 4}, \mathrm{C}_{20: 5}, \mathrm{C}_{22: 6}$. This is very important from the nutritional point of view. The highest contents of $\mathrm{C}_{18: 1}$ and $\mathrm{C}_{16}$ among the identified fatty acids was stated. Lipids of P66 comprised more $\mathrm{C}_{18: 1}$ than remaining muscles and less $\mathrm{C}_{18}$ than P33 and $\mathrm{K} 2$ ones. However lipids of P33 comprised more $\mathrm{C}_{16}$ as compared to the remaining muscles. The highest content of $\mathrm{C}_{20: 4}$ was detected in the K2 muscles. The unsaturated fatty acids (UFA) were predominant in fatty acids composition for all flocks (Table 8). The breeding strains A55 and P66 contained less SFA and considerably more UFA compared with conservative flocks.

Table 8

Balance sheet of fatty acids in breast muscles (Anteile der Fettsäureklassen und deren Relationen in Brustmuskeln)

\begin{tabular}{llllll}
\hline & P33 & K2 & A3 & A55 & P66 \\
\hline SFA (\%) & 42.04 & 38.84 & 38.16 & 34.17 & 34.53 \\
MUFA (\%) & 23.46 & 24.01 & 27.15 & 29.96 & 31.97 \\
PUFA (\%) & 26.66 & 30.44 & 27.62 & 28.92 & 28.67 \\
UFA (\%) & 50.12 & 54.45 & 54.77 & 58.88 & 60.64 \\
n-6 (\%) & 21.31 & 24.85 & 21.08 & 21.31 & 21.62 \\
n-3 (\%) & 4.18 & 4.25 & 5.45 & 6.62 & 6.02 \\
UFA/ SFA & 1.19 & 1.40 & 1.43 & 1.72 & 1.76 \\
PUFA/SFA & 0.63 & 0.78 & 0.72 & 0.84 & 0.83 \\
n-6/n-3 & 5.09 & 5.85 & 3.85 & 3.27 & 3.59 \\
\hline
\end{tabular}

The lipids of P66 comprised the most of UFA especially MUFA, however P33 muscles contained the most of SFA. The highest content of PUFA was established in K2 muscles. The UFA/SFA and PUFA/SFA ratios were more favourable for P66 and A55 selected strains than for conservative flocks. The PUFA/SFA ratios ranged to 0.63-0.84 and were on the higher level for all muscles than recommended (0.4). The $n-$ 6/n-3 PUFA ratios were 3.27-5.85 and they were close to recommended (4-5 ). The lipids of A55 muscles were characterized by the best fatty acid profile among the investigated muscles.

\section{Discussion}

Higher percentage of lipids in breast muscles of different Pekin type and their crossbreds (by 1.3-1.7\%) was found by SMITH et. al. (1993), BONS et al. (1998), 
KNUST (1995), MAZANOWSKI and KSIĄŻKIEWICZ (2004), in comparison with our results. The proportion of moisture in P33 and A3 muscles were higher and in K2, A55, P66 were similar for those reported by WITKIEWICZ (1998 and 2000) for Polish Pekin meat strains (A44, A55, P66, P77) and for the light strain of Pekin ducks by KNUST (1995). The protein content, in the investigated muscles was higher (by 0.73-2.51\%), than that obtained by MAZANOWSKI and KSIAZŻKIEWICZ (2004) for meat type ducks (7- week old) from two sire strains (A44, A55) by GÓRSKA and GÓRSKI (1997) for three and four-breed crosses of Pekin ducks (by 2.41\%) and by WAWRO et al. (2004) for A44 strain ( by 0.63-2.91\%). SMITH et al. (1993) detected a lower protein content (by 2.3\%) in breast muscles of commercial Pekin ducks, too. The considerably higher percentage of lipids (by 4.5-8.5\%) in breast muscles of local and Turkish Pekin reported IŞGUSAR et al. (2002).

The cholesterol content in muscles of investigated flocks ranged from 71.21 to 111.82 mg/100g. Lower cholesterol content was reported for Pekin (HONIKEL and ARNETH, 1996- 67 to 68.5mg/100g; SMITH et al. 1993- 99mg/100g), Muscovy (SALICHON et al., 1997 - 67mg/100g) and force fed Mulard (WOŁOSZYN, 2002$68.6 \mathrm{mg} / 100 \mathrm{~g})$. However BAEZA et al. (2000) detected the cholesterol content in breast muscles of non force fed Mulard ducks on the level 105-117mg/100g.

The fact that available literature provides no information on the amino acid composition in duck muscles makes discussion on this topic difficult. Comparing three conservative flocks and two selected breeding strains with our previous investigation we observed that, the A55 and P66 muscles were characterized by higher level of ILE (by 1-1.5\%), MET + CYS (by 1.0-2.5\% ), VAL (by 1.6\%) and lower of PHE + TYR (by 1.3\%) than muscles from Mulard ( force fed ) and Muscovy ducks (WOŁOSZYN, 2002). However A3, P33 and K2 muscles comprised more TRP (by 0.45\%), MET+CYS (by 1.0-2.8\%) and less PHE+TYR (by 3.0-3.5\%) in comparison with Mulard and Muscovy breast muscles. We stated that TRP was the amino acid limiting biological value of protein for A55 and P66 and ILE and VAL for A2, P33, K2 muscles. The amino acids limiting the biological value of meat protein for Mulard ducks were MET+CYS ( 22-45\%) and TRP (70-75\%). The R index for LYS ( 157.8$174.0 \%$ ) reached the highest value in our investigation. This is in agreement with our own previous results obtained for meat protein from Mulard ducks (WOŁOSZYN et al., 1998; WOŁOSZYN, 2002).

It was stated that in the fatty acids composition, the UFA were predominant and the major fatty acids were the $\mathrm{C}_{18: 1}, \mathrm{C}_{16}$, and $\mathrm{C}_{18: 2}$. The concentration of these fatty acids in lipids from the experimental duck breast muscles were generally similar to those reported by SALICHON et al. (1997) for Muscovy ducks, SMITH et al. (1993) for Pekin ducks and WOŁOSZYN (2002) for Mulard ducks. The data relative to the UFA and the MUFA contents in A3, P33, K2, A55 breast muscles were lower than data previously published by SALICHON et al. (1997) for Muscovy ducks (by 2.2-10.9\% and 2.0-8.54\% respectively), however for P66 were similar to those results. LESKANICH and NOBLE (1997) reported more of the SFA (by 8.26-16.13\%) and less of the UFA (by 5.0-11.14\%\%,) in breast muscles of commercial Pekin ducks in comparison with our results. In the present experiment, the $\mathrm{C}_{16}$ and $\mathrm{C}_{18}$ were predominant among the SFA. The $\mathrm{C}_{16}$ (harmful for human health) content for all flocks was lower than those reported by SMITH et al. (1993), LESKANICH and NOBLE (1997) for Pekin ( by 3.9-7.2\%) and by SALICHON et al. (1997) for 
Muscovy (by 1.2-3.8\%) ducks, however the $\mathrm{C}_{18}$ (which is biologically neutral) generally do not differ.

The muscles from the investigated ducks were characterized by significantly higher PUFA content in comparison with data published by SMITH et al. (1993), LESKANICH and NOBLE (1997) and CHARTRIN et al. (2003) (by 8.7-14\%) for different kinds of Pekin ducks. The UFA/SFA ratios for investigated muscles were lower than for Muscovy (TURI et al., 1994-UFA/SFA $=\sim 1.7$ ) and Mulard (WOŁOSZYN, 2002; CHARTRIN et al., 2003- UFA/SFA = 1.9, 2.1 respectively) ducks. The PUFA/SFA and the n-6/n-3 PUFA ratios were significantly more favourable for investigated muscles than results obtained by SMITH et al. (1993) for Pekin ducks (PUFA/SFA $=0.37, \mathrm{n}-6 / \mathrm{n}-3$ PUFA $=10.0$ ), SALICHON et al. (1997), TURI et al. (1994) for Muscovy ducks (PUFA/SFA $=0.37-0.42, n-6 / n-3$ PUFA $=11.0$ 11.7). This is very important, because preference in human diets is given to the high level of the n-3 PUFA, which is the most valuable acid in the UFA group from the nutritional and physiological points of view. However, comparing all investigated traits it should be mentioned that Pekin and Muscovy originate from two species genetically very distinct from each other.

The breast muscles of selected breeding strains of duck contain more proteins and fat and less cholesterol in comparison to that of conservative flocks. Comparing the basic chemical composition, amino acid composition and profile of fatty acids of lipids, we can conclude, that the A55 breast muscles are the most favourable from the nutrition point of view. Admittedly, they are characterized by the highest content of lipids, however taking into consideration the biological value of proteins, the fatty acids profile and cholesterol content, the A55 breast muscles appeared to be the most suitable. It is evident too, that muscles from all the examined flocks have been characterized by high nutritional value. In spite of the same environmental conditions (feed, housing conditions, age) we observed the differences in chemical composition of breast muscles coming from examined ducks. Probably different physiological mechanisms in the analysed ducks resulted in the differences in chemical composition. Future studies and the investigation of metabolic processes in organism of all kinds of ducks should be conducted for better understanding of the differences observed between genotypes in their ability to deposit and synthesise the amino acids and fatty acids in muscles.

\section{A.O. A.C.: \\ References \\ Official Methods Analysis. 15 ${ }^{\text {th }}$ ed. Association of Official Analytical Chemists. Washington, D.C., 1990}

BAEZA, E.;. SALICHON, M. R.; MARCHE, G.; WACRENIER,G.; DOMINGUEZ, B.; CULIOLI J.:

Effect of age and sex the structural, chemical, technological characteristics of mule duck meat. Brit. Poultry Sci., 41 (2000), 300-307

BONS, A.; TIMLER, R.; JEROCH, H.:

Changes in body composition and content of fat and protein in carcass of male and female Pekin ducks during growth. Zesz. Nauk. Prz. Hod., 36 (1998), 165-175

CHARTRIN, P.; MOUROT, J.; BERNADET, M.;GUY, G.; DUCLOS, M. J.; BAEZA, E.: Effect of genotype and force- feeding on the intramuscular fat deposition in duck. Proceedings of $16^{\text {th }}$ Europ. Symp. on the Quality of Poultry Meat. Saint - Brieuc - Ploufragan (2003), 224-230

GÓRSKA, A.; GÓRSKI, J.:

The change of the total protein, collagen and fat content in Pekin duck crossbreds at the end of rearing period. Proceedings of $13^{\text {th }}$ Europ. Symp. on the Quality of Poultry Meat, Poznań (1997), 334-337 
FOLCH, J.; LESS, M.J.; SLOANE, STANLEY G. H.:

A simple method for the isolation and purification of total lipides from animal tissues. J. Biol. Chem., 226 (1957), 437-439

HONIKEL, K.O.; ARNETH, W.:

Cholesterol in meat and eggs. Fleischwirtschaft, 12, (1996), 1244, 1246-1248, 1253, 1329

IŞGUSAR, E.; KOCAK, C.; PINGEL, H.:

Growth, carcass traits and meat quality of different local ducks and Turkish Pekins. Arch. Tierz., Dummerstorf, 45 ( 2002), 413-418

KISIEL, T.; KSIAŻKIEWICZ, J.:

Comparison of physical and qualitative traits of meat of two Polish conservative flocks of ducks. Arch. Tierz., Dummerstorf, 47 (2004), 367-375

KNUST, U.:

Untersuchungen zur Charakterisierung der Wirkung von prä- and postmortalen Faktoren auf die Schlachtkörperzusammensetzung, die Muskelfaserzusammensetzung und die Fleischqualität von Enten. Diss., Univ. Halle, 1995

KSIĄŻKIEWICZ, J.:

Characteristics of meatiness traits in six generations of ducks in conservative groups. J. Anim. Feed Sci. 1 (1997), 101-108

KSIĄŻKIEWICZ, J.:

Reproductive and meat characteristics of Polish ducks threatened with extinction. Czech J. Anim. Sci., 47 (2002), 401-410

KSIĄŻKIEWICZ, J.:

Comparison of reproduction and carcass traits in light type of ducks of four conservative flocks over eight generations. Arch. Tierz., Dummerstorf, 46 (2003), 377-389

LESKANICH, C.O.; NOBLE, R. C.:

Manipulation of the n-3 PUFA composition of avian eggs and meat. World's Poultry Sci. J. 53 (1997), 155-183

MAZANOWSKI, A.; KSIĄŻKIEWICZ, J.:

Comprehensive evaluation of meat traits of ducks from two sire strains. J. Anim. Feed Sci. 13 (2004), 175-184.

MAZANOWSKI, A.:

Breeding strains of ducks and their crossbreeds ( in Polish). Wyd. Inst. Zootechniki, Balice k. Krakowa, B-2, (2002)

PFEUFFER, M.:

Physiologic effects of individual fatty acids in animal and human body, with particular attention to coronary heart disease risk modulation. Arch. Tierz., Dummerstorf, 44 (2001), 89-98

PINGEL, H.:

Enten. VEB Deutscher Landwirtschaftverlag, Berlin, 1988

PRESCHA, A.; ŚWIĘDRYCH, A.; BIERNAT, J.; SZOPA, J: Increase in lipid content in potato tubers modified by 14-3-3 gene over expression. J. Agric. Food Chem., 49 (2001), 3638-3643

RHEE, K.S.; DUTSON, T. R.; SMITH, G. T.; HOSTELLER, R. L.; REISEL, R.:

Cholesterol content of raw and cooked beef Longissimus Muscles with different degrees of marbling. J. Food Sci., 47 (1982), 716

SALICHON, R. M.; BAEZA, E.; LECLERCQ, B.:

Biochemical characteristics of Muscovy duck breast. Sciences des Aliments, 17 (1997), 227-233

SKRABKA-BŁOTNICKA, T.:

The investigation of changes procceded in proteins and amino acids from broiler chicken muscles during freezig, storage and defrosting (in Polish). Inst. Zoot., P.W.N. Warszawa-Wrocław, 5, 1973

SKRABKA-BŁOTNICKA, T.; ROSIŃSKI, A.; PRZYSIĘŻNA, E.; WOŁOSZYN, J.; ELMINOWSKAWENDA, G.:

The effect of dietary formulation supplemented with herbal mixture on the goose breast muscle quality. The effect on the chemical composition. Arch. Geflügelk., 61 (1997), 135-138

SMITH, D.P.; FLETCHER, D. L.; BUHR, J. R.; BEYER, D.S.:

Pekin duckling and broiler Pectoralis Muscle structure and composition. Poultry Sci. 72 (1993), 202208

STATSOFT. INC. STATISTICA-

Data analysis software system, version 6.0, Tulsa OK, USA, (2001)

TURI, R.M.; SACCHI, P.; ROMBOLI I.: 
Carcass composition and meat quality of Muscovy ducks in response to clenbuterol administration. Arch. Geflügelk., 58 (1994), 257-261

WAWRO, K.; WILKIEWICZ-WAWRO; E; KLECZEK, K; BRZOZOWSKI, W.:

Slaughter value and meat quality of Muscovy ducks, Pekin ducks and their crossbreeds, and evaluation of the heterosis effect. Arch. Tierz., Dummerstorf, 47 (2004), 287-299

WITKIEWICZ, K.:

Comparison of ducks from two breeding strains with regard to some selected live and slaughter traits (in Polish). Rocz. AR Pozań, 302 (1998), 243-251

WITKIEWICZ, K.:

Zoometric measurements, slaughter value and chemical composition of the breast muscle in two strains of ducks of Pekin type (in Polish). Rocz. AR Poznań 330 (2000), 231-240

WOŁOSZYN, J.; SKRABKA-BŁOTNICKA T.; PRZYSIĘŻNA E.:

The chemical composition of Mullard duck muscles. $10^{\text {th }}$ European Poultry Conference. Jerusalem, (1998), Abstracts, 110

WOŁOSZYN, J.:

The physicochemical and technological characteristic of muscles from force fed ducks (in Polish). Wyd. AE Wrocław, 145, 2002

WORLD WATCH LIST FOR DOMESTIC ANIMAL DIVERSITY:FAO, UNDP, $3^{\text {rd }}$ edition, Roma, (2000)

Received: 2005-09-07

Accepted: 2006-03-14

Corresponding Author

JANINA WOŁOSZYN PhD, DSc.

University of Economics, Department of Animal Food Technology

Komandorska 118/120

53-345 Wrocław

Poland

E-Mail: janina.woloszyn@ae.wroc.pl 